\title{
New Insights on the Anticancer Properties of Dietary Polyphenols
}

\author{
P. Fresco, ${ }^{1}$ F. Borges, ${ }^{2,3}$ C. Diniz, ${ }^{1}$ M.P.M. Marques ${ }^{3,4}$ \\ 'Laboratório de Farmacologia, Faculdade de Farmácia, da Universidade do Porto, Portugal \\ ²Laboratório de Química Orgânica, Faculdade de Farmácia, \\ da Universidade do Porto, Portugal \\ 3Unidade "Química-Física Molecular", Universidade de Coimbra, \\ Portugal \\ ${ }^{4}$ Departmento de Bioquímica, Faculdade de Ciências e \\ Tecnologia, Universidade de Coimbra, Portugal
}

Published online 18 May 2006 in Wiley InterScience (www.interscience.wiley.com).

DOI 10.1002/med.20060

\begin{abstract}
Cancer, one of the major causes of death across the world, has shown to be a largely preventable disease, highly susceptible to modulation by dietary factors. Phenolic compounds, abundant in vegetables and fruits ubiquitous in diet, were described to play an important role as chemopreventive agents. Since conventional therapeutic and surgical approaches have not been able to control the incidence of most cancer types, the development of chemopreventive strategies is an urgent priority in public health. The current diet phenolic intake is often insufficient to protect from mutagens (either exogenous or endogenous), which leads to the need for dietary supplementation as an alternative approach. Research efforts are placing increasing emphasis on identifying the biological mechanisms and in particular the signal transduction pathways related to the chemopreventive activities of these compounds. These effects are believed to occur by the regulation of signaling pathways such as nuclear factor- $\mathrm{\kappa B}(\mathrm{NF}-\mathrm{\kappa B})$, activator protein-1 (AP-1) or mitogen-activated protein kinases (MAPK). Dietary polyphenols can exert their effects on these pathways separately or sequentially and in addition the occurrence of crosstalk between these pathways cannot be overlooked. By modulating cell signaling pathways, polyphenols activate cell death signals and induce apoptosis in precancerous or malignant cells resulting in the inhibition of cancer development or progression. However, regulation of cell signaling pathways by dietary polyphenols can also lead to cell proliferation/survival or inflammatory responses due to increased expression of several genes. The present review summarizes the most recent advances providing new insights into the molecular mechanisms underlying the promising anticarcinogenic activity of dietary polyphenols. ๑ 2006 Wiley Periodicals, Inc. Med Res Rev, 26, No. 6, 747-766, 2006
\end{abstract}

Key words: dietary polyphenols; anticancer; chemoprevention; structure-activity relationships

Correspondence to: P. Fresco, Laboratório de Farmacologia, Faculdade de Farmácia, Universidade do Porto, Portugal. E-mail: pfresco@ff.up.pt 


\section{BACKGROUND}

The major stages of carcinogenesis, delineated over the past 50 years, encompass chronic events such as initiation, promotion, and progression. ${ }^{1}$ Tumor initiation begins when DNA, in a cell or population of cells, is damaged by exposure to carcinogens. If this injury escapes repair it can lead to genetic mutations. The tumor promotion stage is characterized by selective clonal expansion of the initiated cells, as a result of the altered expression of genes whose products are associated with hyperproliferation, tissue remodeling, and inflammation. ${ }^{1}$ During progression, preneoplastic cells develop into tumors through a process of clonal expansion, facilitated by progressive genomic instability and altered gene expression. ${ }^{2}$ It is presently accepted that human carcinogenesis does not occur through these three discrete fases in a predictable manner, rather it is best characterized as an accumulation of alterations in cancer regulating genes, such as oncogenes, tumor suppressor, apoptosis-regulating, and DNA-repair genes. ${ }^{3}$ The animal models of multistage carcinogenesis have greatly contributed to the current knowledge of this process and of the possible ways to interfere with it. The most rational way to affect carcinogenesis is by interfering with those steps amenable to be modulated, as well as the associated signal transduction pathways.

Chemoprevention comprises multiple intervention strategies, using either pharmacological or dietary agents to prevent, arrest or reverse the carcinogenesis process at various stages. ${ }^{4}$ Experimental and epidemiological studies showed that more than $90 \%$ of cancers are associated with both mutagens and mitogens. ${ }^{5,6}$ Therefore, chemoprevention strategies should be mostly concerned with substances which are able to inhibit or reverse these cellular processes, namely decreased apoptosis, increased proliferation, and cell maturation or differentiation. Conventional classification of chemopreventive agents ${ }^{7,8}$ is based on the underlying mechanisms by which they exert their protective effects in a specific stage of multistep carcinogenesis: blocking and suppressing agents. Blocking agents can hamper initiation either by inhibiting carcinogen formation from procarcinogens or by preventing the ultimate electrophilic and carcinogenic species from interacting with critical cellular target molecules such as DNA, RNA, and proteins. ${ }^{8}$ Suppressing agents, in turn, inhibit expression of initiated cells either in the promotion or progression stages. ${ }^{9}$ Despite the great advances on the understanding of the beneficial effects of several chemopreventive substances, particularly on different carcinogenesis-related signal transduction pathways, this is still an area undergoing extensive research. The major part of research concerning signal transduction pathways, for instance, has been carried out in cell lines (in vitro) although it is not clear whether some of the phenomena observed in these simpler systems can also occur in vivo.

The chemopreventive agents found in the human diet are a very promising group of compounds, on account of their safety, low-toxicity, and general acceptance. Indeed, numerous phenolic compounds have been investigated for their potential use as cancer chemopreventive agents. ${ }^{10-13}$ Naturally occurring phenolic acids and analogs (e.g., caffeic and gallic acids) are known to display a wide variety of biological functions, in addition to their primary antioxidant activity, which are mainly related to modulation of carcinogenesis. ${ }^{10-13}$ Thus, phenolic derivatives have lately received increased attention, namely the ones which are taken exogenously from the diet (as nutritional supplements).

Several epidemiological studies indicate that a diet rich in fruits and vegetables is associated to the reduction of cancer risk in humans, suggesting that certain dietary constituents may thus be effective in preventing cancer. ${ }^{14}$ Consequently, the identification and development of cancer chemopreventive phenolic agents has become, in the last few years, a most relevant issue in public health-related research. Phenolic compounds constitute one of the most numerous and ubiquitous groups of plant metabolites, and are an integral part of the human diet.

The present work is not intended as an exhaustive revision on this subject, but as a description of the most recent studies on the anticancer activity of dietary polyphenolic compounds. One of the main goals of this area of research is the full evaluation and characterization, at a 
molecular level, of this type of effects, to exploit the potential of polyphenols as chemopreventive agents.

\section{CHEMISTRY OF DIETARY POLYPHENOLS}

Polyphenolic compounds constitute a diverse group of secondary metabolites that are present in the human diet. This group of heterogeneous compounds correspond to a wide variety of chemopreventive agents and has been categorized in the following groups: Phenolic acids and analogs (Table I), Stilbenes (Table II), Flavonoids and analogs (Table III), Miscellaneous (Table IV). Tables I-IV comprise relevant information on the most actively studied polyphenolic compounds, from 2000 to this date.

\section{A. Phenolic Acids and Analogs}

The phenolic acids are usually divided in two main groups: benzoic acids, containing seven carbon atoms $(\mathrm{C} 6-\mathrm{C} 1)$, and cinnamic acids, comprising nine carbon atoms $(\mathrm{C} 6-\mathrm{C} 3)$. These compounds exist predominantly in the hydroxylated form, therefore being generally named hydroxybenzoic and hydroxycinnamic acids, respectively. Several types of hydroxybenzoic and hydroxycinnamic acids have been identified in the human diet, and are known to play an important role due to their abundance and diversity. Natural phenolic acids, either occurring in the free or conjugated forms, usually appear as esters or amides ${ }^{12,13}$ (Table I). Due to their structural similarity, several other polyphenols are considered as acid analogs (Table I). For instance, the phenylethanol derivatives, with eight carbon atoms (C6-C2), which comprise the 3,4-dihydroxyphenylethanol (hydroxytyrosol) and the 4hydroxyphenylethanol (tyrosol), are also considered as chemopreventive components of diet.

\section{B. Stilbenes}

Stilbenes are phenolic compounds displaying two aromatic rings linked by an ethene bridge. Resveratrol (3,5,4'-trihydroxystilbene) is the member of this chemical family more abundant in the human diet, namely in grapes and wine.

Other stilbenes that have recently been identified in the diet, such as piceatannol glucoside (usually named astringin) and pterostilbene, are also considered as potential chemopreventive agents (Table II).

\section{Flavonoids and Analogs}

Flavonoids belong to a chemical class of polyphenols presenting a basic structure of 15 carbon atoms, comprising two aromatic rings bound through a 3 carbon chain (C6-C3-C6), which can eventually be part of a third ring. This type of carbon skeleton, as well as the conformation of the central chain, is responsible for the chemical diversity of these compounds.

In nature, flavonoids can occur either in the free or conjugated forms, often being esterified to one or two sugar molecules, through at least one hydroxyl group ( $O$-glucosides, $O$-Gluc) (Table III). Silymarin, a flavonoid analog worth referring, is also included in Table III.

\section{Miscellaneous}

\section{Coumarins}

Coumarins are lactones obtained by cyclization of cis-ortho-hydroxycinnamic acid. This precursor is formed through isomerization and hydroxylation processes of the structural analogs transhydroxycinnamic and derivatives. In general, coumarins are characterized by great chemical diversity, mainly differing in the oxygenation degree of their benzopyrane moiety. In nature, most of coumarins are $\mathrm{C}_{7}$-hydroxylated (Table IV). 
Table I. Phenolic Acids and Analogs

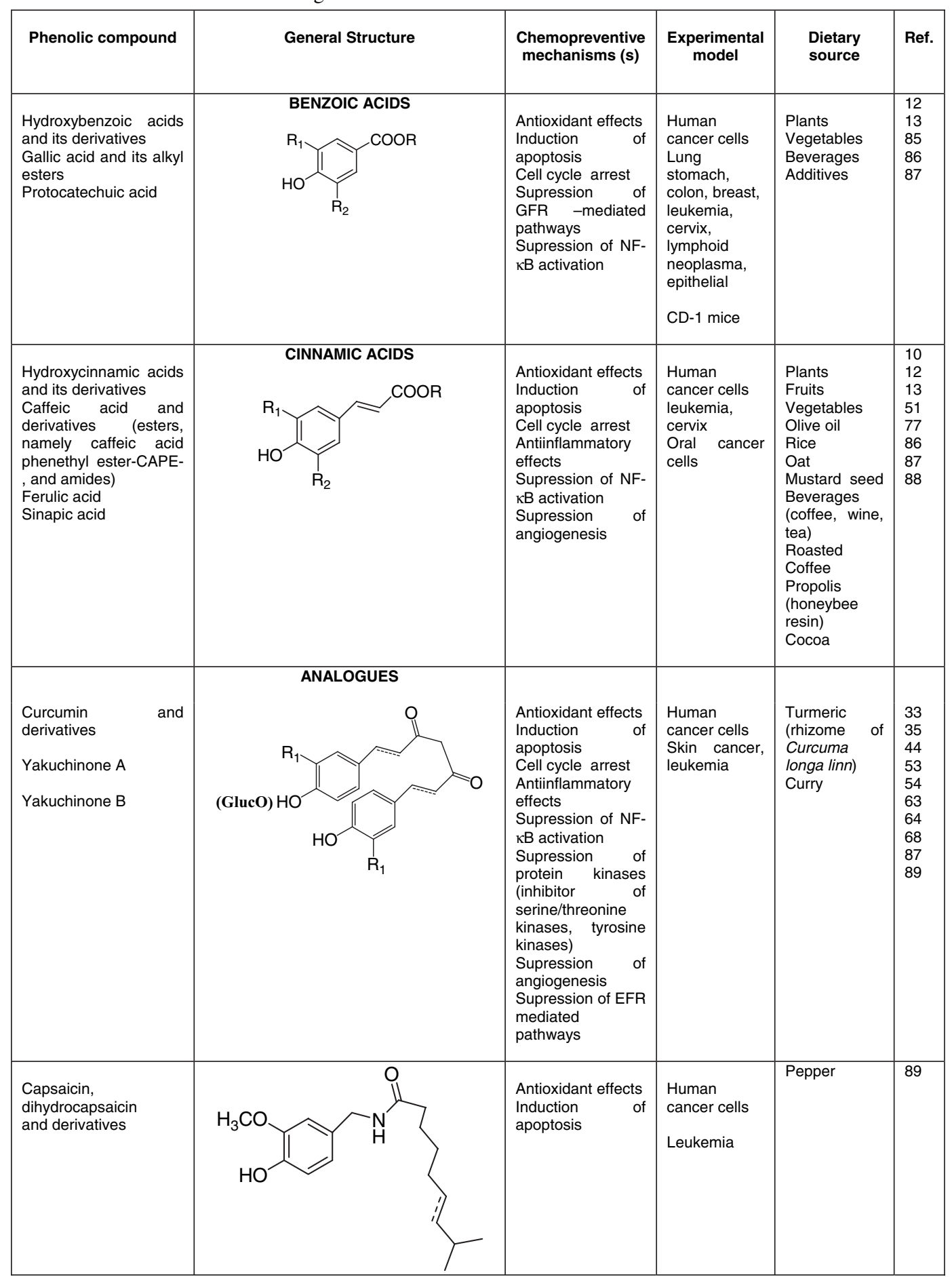


Table I. (Continued)

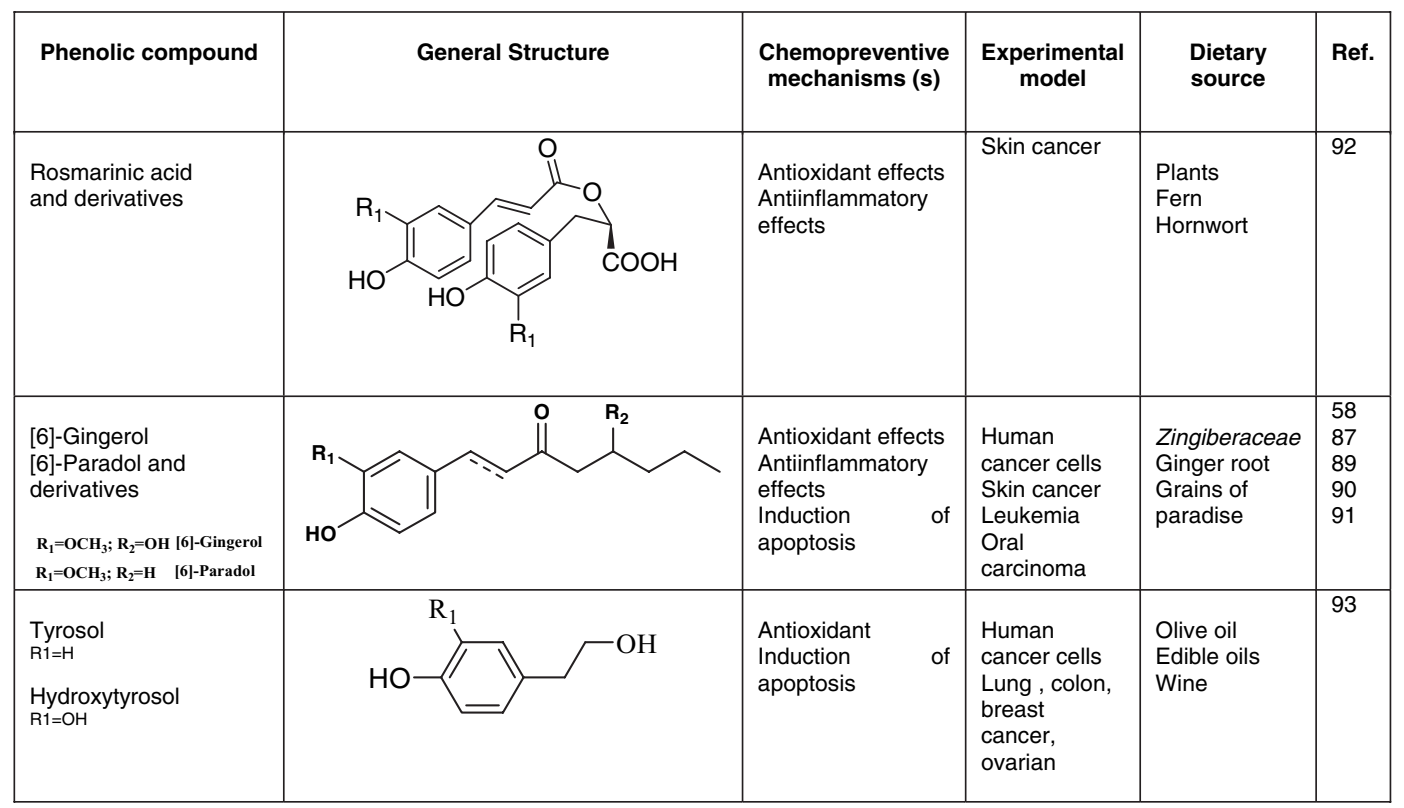

\section{Lignans}

Lignans are dimers (with two C6-C3 units) resulting from tail-to-tail linkage of two coniferyl or sinapyl alcohol units. Sesamol and its glucosides are good examples of this type of compounds (Table IV).

\section{Tannins}

Tannins are polyphenolic compounds usually classified in two classes: the hydrolysable and the nonhydrolysable (or condensed) tannins. The former are complex polyphenols, which can be degraded

Table II. Stilbenes

\begin{tabular}{|c|c|c|c|c|c|}
\hline $\begin{array}{l}\text { Phenolic } \\
\text { compound }\end{array}$ & General Structure & $\begin{array}{c}\text { Chemopreventive } \\
\text { mechanism(s) }\end{array}$ & $\begin{array}{c}\text { Experimental } \\
\text { model }\end{array}$ & $\begin{array}{l}\text { Dietary } \\
\text { source }\end{array}$ & Ref. \\
\hline $\begin{array}{l}\text { Trans- } \\
\text { Resveratrol } \\
\text { and } \\
\text { derivatives }\end{array}$ & $\begin{array}{l}\mathrm{R}_{1} \mathrm{O} \\
\mathrm{R}_{1}=\mathrm{R}_{2}=\mathrm{H} \text {; trans-resveratrol } \\
\mathrm{R}_{1}=\mathrm{H}, \mathrm{R}_{2}=\mathrm{Gluc} \text {; trans-piceid } \\
\mathrm{R}_{1}=\mathrm{CH}_{3}, \mathrm{R}_{2}=\mathrm{CH}_{3} \text {; trans-pterostilbene }\end{array}$ & $\begin{array}{l}\text { Antioxidant effects } \\
\text { Induction of } \\
\text { apoptosis } \\
\text { Cell cycle arrest } \\
\text { Antiinflammatory } \\
\text { effects } \\
\text { Supression of NF-kB } \\
\text { activation } \\
\text { Supression } \\
\text { angiogenesis } \\
\text { Supression of protein } \\
\text { kinases (PTKs) } \\
\text { Supression of } \\
\text { antiangiogenis } \\
\text { Cell cycle arrest } \\
\text { Supression of AP-1 } \\
\text { activation } \\
\text { Supression of EGR- } \\
\text { mediated pathways }\end{array}$ & $\begin{array}{l}\text { Human cancer } \\
\text { cells: } \\
\text { colon, prostate, } \\
\text { breast, leukemia, } \\
\text { epithelial } \\
\text { esophageal, } \\
\text { ovarian, gastric, } \\
\text { skin } \\
\text { metastatic breast } \\
\text { cancer cells } \\
\text { Preneoplastic } \\
\text { lesions } \\
\text { Animal models } \\
\text { RT-2 rat gliomas }\end{array}$ & $\begin{array}{l}\text { Grapes } \\
\text { Wine } \\
\text { Ko-jo-kon } \\
\text { (root } \\
\text { Ploygonum } \\
\text { cuspidatum) }\end{array}$ & $\begin{array}{l}20 \\
24 \\
27 \\
36 \\
42 \\
43 \\
47 \\
52 \\
55 \\
56 \\
57 \\
68 \\
71 \\
89 \\
91\end{array}$ \\
\hline
\end{tabular}


into sugars and phenolic acids through either $\mathrm{pH}$ changes, or enzymatic or non-enzymatic hydrolysis. The basic units of hydrolysable tannins of the polyester type is the gallic acid and its derivatives (Table IV).

\section{CHEMOPREVENTIVE MECHANISMS OF POLYPHENOLS}

Cancer has proved to be a largely preventable disease, namely through an appropriate diet. Actually, since conventional therapeutic and surgical approaches have not been able to control the incidence of most cancer types, there is an urgent need to develop mechanism-based strategies in order to achieve this goal. Prevention via non-toxic agents may be one such approach. ${ }^{15}$

Table III. Flavonoids and Analogs

\begin{tabular}{|c|c|c|c|c|c|}
\hline Phenolic compound & General Structure & $\begin{array}{c}\text { Chemopreventive } \\
\text { mechanism(s) }\end{array}$ & $\begin{array}{l}\text { Experimental } \\
\text { model }\end{array}$ & $\begin{array}{l}\text { Dietary } \\
\text { source }\end{array}$ & Ref. \\
\hline $\begin{array}{l}\text { Catechin } \\
\mathrm{R}_{1}=\mathrm{R}_{2}=\mathrm{R}_{3}=\mathrm{R}_{4}=\mathrm{R}_{5}=\mathrm{R}_{6}=\mathrm{OH} \\
\text { Epicatechin } \\
\mathrm{R}_{1}=\mathrm{R}_{2}=\mathrm{OH} ; \mathrm{R}_{3}=\mathrm{R}_{4}=\mathrm{H} ; \mathrm{R}_{5}= \\
\mathrm{R}_{6}=\mathrm{OH}\end{array}$ & Flavanol & $\begin{array}{l}\text { Antioxidant effects } \\
\text { Antiinflammmatory } \\
\text { effects } \\
\text { Inhibition of } \\
\text { telomerase }\end{array}$ & $\begin{array}{l}\text { Human } \\
\text { cancer cells: } \\
\text { prostate, } \\
\text { breast }\end{array}$ & $\begin{array}{l}\text { Apple skin } \\
\text { Celery } \\
\text { Berries } \\
\text { Citrus fruits } \\
\text { Soybeans } \\
\text { Onions } \\
\text { Green tea } \\
\text { Cocoa }\end{array}$ & $\begin{array}{l}68 \\
70 \\
74 \\
84 \\
87 \\
94 \\
96\end{array}$ \\
\hline $\begin{array}{l}\text { Quercetin } \\
\mathrm{R}_{1}=\mathrm{O} ; \mathrm{R}_{5}=\mathrm{H}=\mathrm{R}_{3}=\mathrm{OH} ; \\
\mathrm{R}_{4}=\mathrm{OH} ; \\
\text { Myricetin } \\
\mathrm{R}_{1}=\mathrm{R}_{2}=\mathrm{R}_{3}=\mathrm{R}_{4}=\mathrm{R}_{5}=\mathrm{OH} \\
\text { Galantin } \\
\mathrm{R}_{1}=\mathrm{R}_{2}=\mathrm{OH} ; \mathrm{R}_{3}=\mathrm{R}_{4}=\mathrm{R}_{5}=\mathrm{H}\end{array}$ & Flavonol & $\begin{array}{l}\text { Antioxidant effects } \\
\text { Antiinflammatory } \\
\text { effects } \\
\text { Induction } \\
\text { apoptosis } \\
\text { Supression of NF- } \\
\text { KB activation } \\
\text { Supression of } \\
\text { protein kinases } \\
\text { (PTKs) } \\
\text { Suppression of } \\
\text { angiogenesis } \\
\text { Cell cycle arrest of } \\
\text { Inhibitor } \\
\text { telomerase of }\end{array}$ & $\begin{array}{l}\text { Human } \\
\text { cancer cells: } \\
\text { Breast, } \\
\text { ovarian, } \\
\text { leukemia, } \\
\text { colon, lung, } \\
\text { oral cancer, } \\
\text { prostate }\end{array}$ & $\begin{array}{l}\text { Olive oil } \\
\text { Red wine } \\
\text { Tea } \\
\text { Citrus fruits } \\
\text { Tomato } \\
\text { Onion } \\
\text { Cotton } \\
\text { seed } \\
\text { Yellow } \\
\text { vegetables }\end{array}$ & $\begin{array}{l}45 \\
68 \\
70 \\
74 \\
84 \\
87 \\
94 \\
95 \\
96\end{array}$ \\
\hline $\begin{array}{l}\text { Baicalin } \\
\mathrm{R}_{1}=\mathrm{OGluc} ; \mathrm{R}_{2}=\mathrm{R}_{3}=\mathrm{OH} ; \\
\mathrm{R}_{4}=\mathrm{R}_{5}=\mathrm{OH} \\
\text { Luteonin } \\
\mathrm{R}_{1}=\mathrm{OH} ; \mathrm{R}_{2}=\mathrm{H} \quad \mathrm{R}_{3}=\mathrm{OH} ; \\
\mathrm{R}_{4}=\mathrm{R}_{5}=\mathrm{OH} \\
\text { Apigenin } \\
\mathrm{R}_{1}=\mathrm{OH} ; \mathrm{R}_{2}=\mathrm{H} ; \mathrm{R}_{3}=\mathrm{OH} ; \mathrm{R}_{4}=\mathrm{OH} ; \\
\mathrm{R}_{5}=\mathrm{H}\end{array}$ & Flavone & $\begin{array}{l}\text { Induction of } \\
\text { apoptosis } \\
\text { Antiinflammatory } \\
\text { effects } \\
\text { Supression of } \\
\text { MAPKs } \\
\text { Cell cycle arrest } \\
\text { Supression of NF- } \\
\text { KB activation }\end{array}$ & $\begin{array}{l}\text { Human } \\
\text { cancer cells: } \\
\text { Hepato, } \\
\text { prostate, } \\
\text { leukemia- } \\
\text { derived T cell } \\
\text { line; breast, } \\
\text { thyroid, } \\
\text { Skin cancer }\end{array}$ & $\begin{array}{l}\text { Herbal } \\
\text { medicine } \\
\text { Legumes } \\
\text { Broccoli } \\
\text { Parsley } \\
\text { Thyme } \\
\text { Olives } \\
\text { Cherries } \\
\text { Tea }\end{array}$ & $\begin{array}{l}30 \\
33 \\
87 \\
94\end{array}$ \\
\hline $\begin{array}{l}\text { Genistein } \\
\mathrm{R}_{1}=\mathrm{R}_{2}=\mathrm{R}_{3}=\mathrm{OH}\end{array}$ & Isoflavone & $\begin{array}{l}\text { Antioxidant effects } \\
\text { Induction of } \\
\text { apoptosis } \\
\text { Antiinflammatory } \\
\text { effects } \\
\text { Supression of } \\
\text { protein kinases } \\
\text { (PTKs) } \\
\text { Cell cycle arrest } \\
\text { Suppression of } \\
\text { angiogenesis }\end{array}$ & $\begin{array}{l}\text { Human } \\
\text { cancer cells: } \\
\text { Breast } \\
\text { leukemia, } \\
\text { prostate, } \\
\text { colon }\end{array}$ & $\begin{array}{l}\text { Soybean } \\
\text { Citrus fruits } \\
\text { Red clover }\end{array}$ & $\begin{array}{l}34 \\
60 \\
61 \\
94 \\
96\end{array}$ \\
\hline
\end{tabular}


Table III. (Continued)

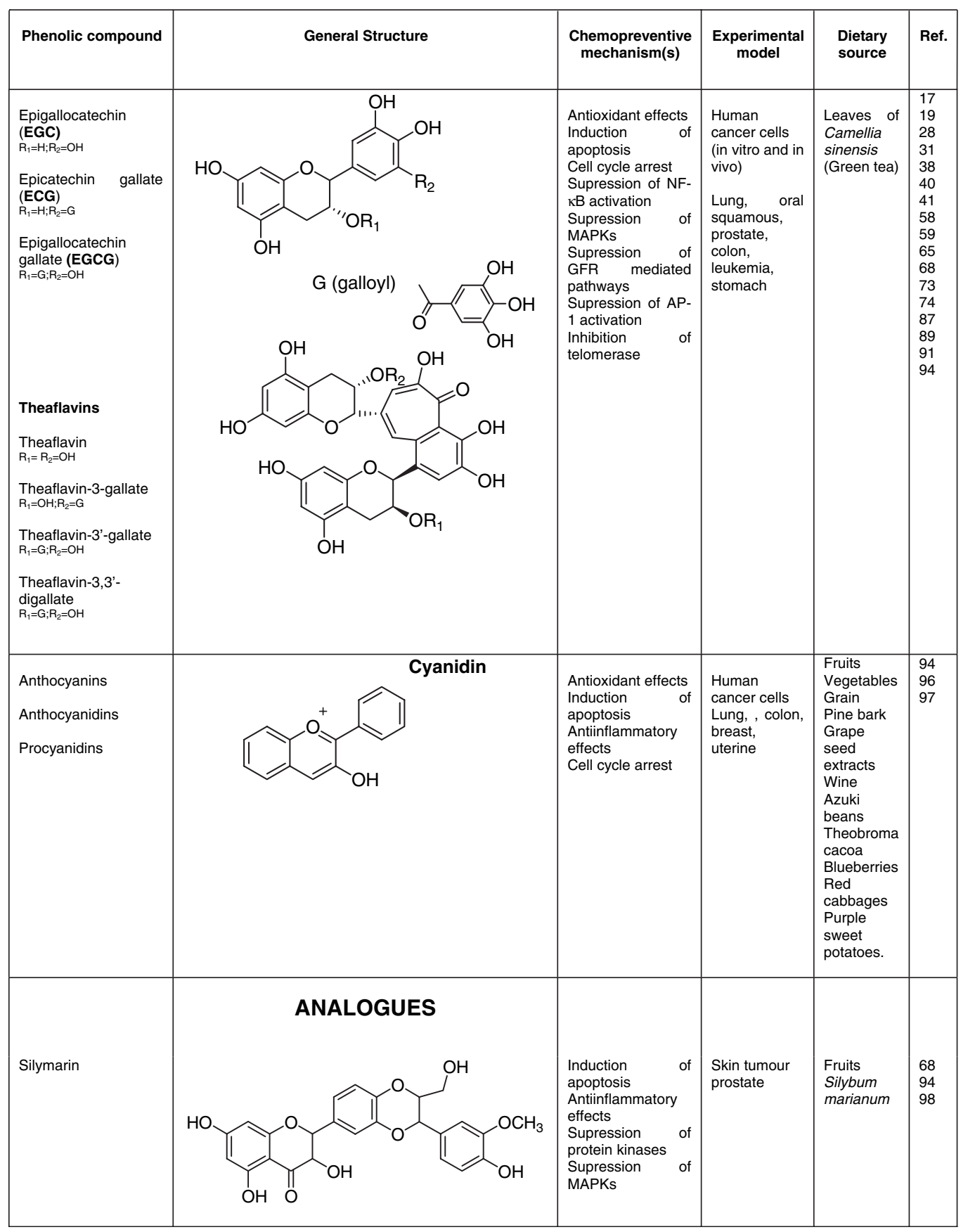

The cellular signaling pathways that regulate proliferation, survival and transformation of cells are of particular interest in current cancer biology. Many of the molecular alterations associated with carcinogenesis occur in cell signaling pathways that regulate cell proliferation and differentiation. Components of these pathways include several kinases such as mitogen-activated protein kinases (MAPK) and protein kinase C (PKC) which contribute to the maintenance of cell homeostasis. Abnormal activation or silencing of these kinases or their downstream transcription factors can result 
Table IV. Miscellaneous

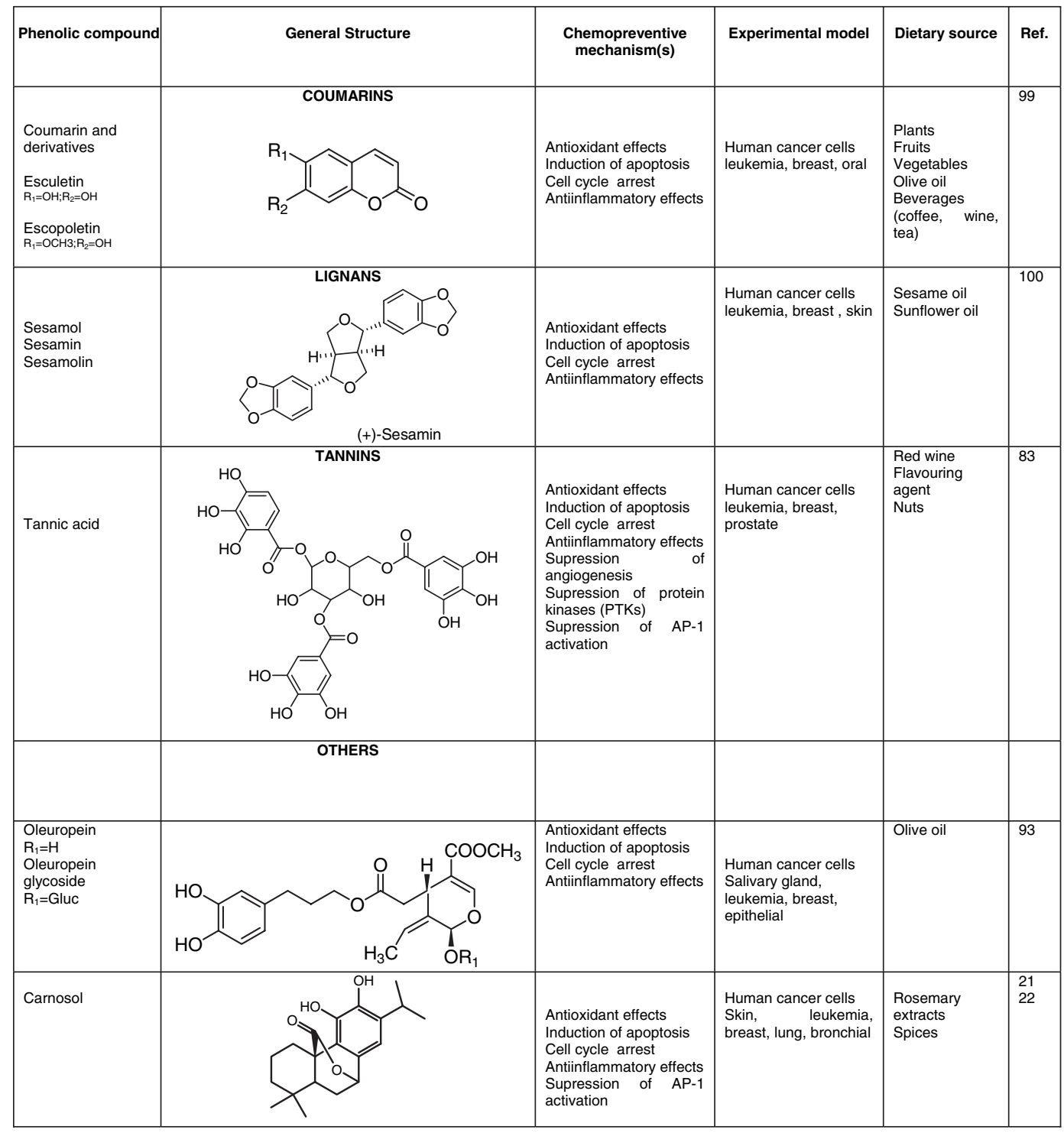

in uncontrolled cell growth, leading to malignant transformation. This section will describe the effects of phenolic compounds on signal transduction pathways related to the carcinogenesis process. Figure 1 depicts some of the possible mechanisms underlying phenolic chemopreventive properties.

\section{A. Suppression of NF-кB Transcription Factor Activation}

Nuclear factor- $\kappa \mathrm{B}(\mathrm{NF}-\kappa \mathrm{B})$ is a nuclear transcription factor that regulates the expression of various genes involved in inflammation and carcinogenesis, being normally inactive in the cytosol bound to inhibitor $\kappa \mathrm{B}(\mathrm{I}-\kappa \mathrm{B}){ }^{8}$ Phosphorylation of I- $\kappa \mathrm{B}$ by I- $\kappa \mathrm{B}$ kinases (IKK) leads to its degradation freeing $\mathrm{NF}-\kappa \mathrm{B}$, which can then translocate into the nucleus activating expression of c-myc, iNOS, and other proliferative genes. ${ }^{16}$ Examples of phenolic compounds which can interfere with this pathway are resveratrol, carnosol, and epigallocatechin-3-gallate (EGCG) (Tables II-IV, respectively). The latter was reported to inhibit the activity of IKK in tumor necrosis factor alpha (TNF $\alpha$ )-stimulated IEC-6 


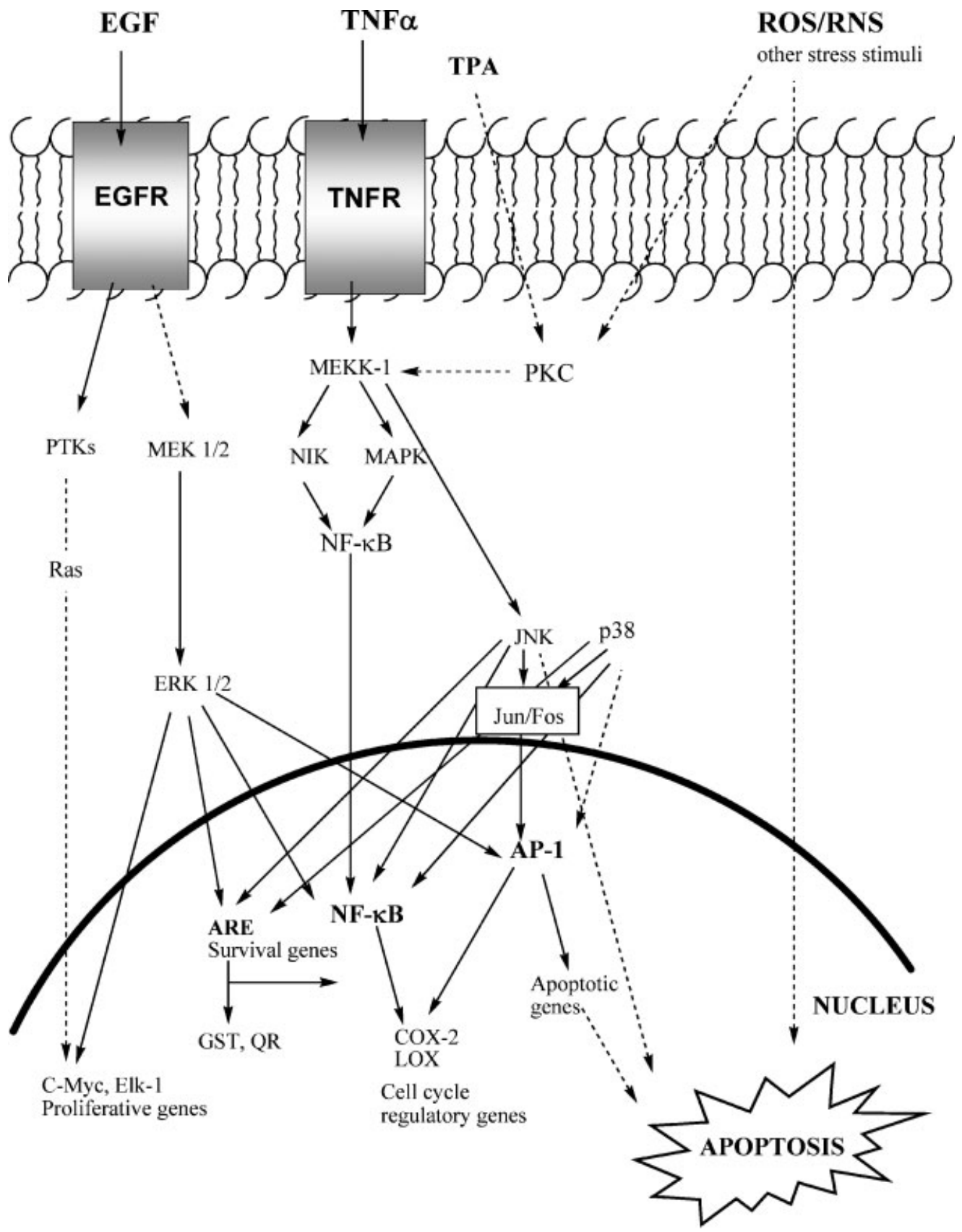

Figure 1. Extracellular growth factors, cytokines or tumor promoters can bind to membrane receptors such as epidermal growth factor receptor (EGFR), tumor necrosis factor receptor (TNFR), or protein kinase C (PKC) activating several serine/threonine or tyrosine kinases, namely Ras, NF- $\kappa$ B inducing kinase (NIK), mitogen-activated protein kinase (MAPK), extracellular response kinase (ERK), MAPK/ERK kinase kinase (MEKK-1), and c-jun N-terminal kinase (JNK). JNK is activated by MAPK kinase (MEKK-1) increasing the activity of several transcription factors and subsequent gene expression, which can lead to cell proliferation (increased expression of proliferation genes), survival (activation of antioxidant response element and induction of phase II genes which leads to increased expression of defense enzymes such as GSH or QR), inflammatory (expression of enzymes involved in the inflammatory response such as COX-2 and LOX) or apoptotic responses. These pathways are described as possible targets for chemoprevention. Reactive oxygen/nitrogen species (ROS/RNS) and other stress stimuli can also activate these signaling pathways or cause apoptosis independently of those. 
intestinal epithelial cells, ${ }^{17}$ lipopolysaccharide (LPS)-stimulated RAW 264.7 cells. ${ }^{18}$ In addition, it is known to inhibit the activity of NF- $\mathrm{KB}$ in TNF $\alpha$ and LPS-stimulated A431 human epidermoid carcinoma cells. ${ }^{19}$ Resveratrol, in turn, blocks TNF $\alpha$-induced NF- $\kappa B$ activation in U-937 myeloid, Jurkat lymphoid, and epithelial HeLa and $\mathrm{H} 4$ cells, ${ }^{20}$ while carnosol blocks NF- $\kappa \mathrm{B}$ translocation and DNA binding in LPS-activated mouse macrophages ${ }^{21}$ and in B16/F10 mouse melanoma cells. ${ }^{22}$ Phenolic acids and their analogs (Table I) can also act through this chemopreventive mechanism. ${ }^{12,13}$

\section{B. Suppression of AP-1 Transcription Factor Activation}

Activator protein-1 (AP-1) is a transcription factor transactivated by several tumor-promoting agents. ${ }^{23}$ AP-1 can be produced by different dimeric combinations of proteins from the Jun and Fos family, Jun dimerization partners (JDP1 and JDP2) and the closely related activating transcription factor (ATF2, LRF1/ATF3, and B-ATF) subfamilies, which are bZIP proteins. ${ }^{24}$ Jun proteins can form stable dimers that bind to a specific target DNA site (5'-TGAG/CTCA-3') known as TPA response element (TRE) in the promoters of several genes, mediating early gene expression involved in several transcriptional regulation processes. ${ }^{23}$ It has also been shown to play a critical role in cell proliferation. ${ }^{24}$ Fos family proteins do not form stable dimers, but can yield heterodimers with Jun proteins $^{25}$ able to bind to DNA at the major MAPK-responsive element in the c-fos promoter, serum response element (SRE). ATF proteins, in turn, are capable of forming both homo and heterodimers with Jun protein, preferentially binding to $5^{\prime}$-TGACGTCA-3', known as cyclic AMP response element (CRE). ${ }^{26}$

In most cancer cell lines, AP-1 is highly activated, and polyphenols (theaflavin, EGCG, and resveratrol) were described to inhibit the transcriptional activity of AP-1 by TNF- $\alpha$, PMA, and UV radiation. ${ }^{27-29}$ In addition, the mechanism behind this decreased activity seems to be the blockade of the ERK2, JNK-1, and p38 MAPK activation, ${ }^{27}$ which are the upstream kinases that regulate activation of both NF-kB and AP-1. ${ }^{24}$

\section{Suppression of Mitogen Activated Protein Kinases (MAPK)}

Some phenolic compounds, in addition to other factors, ${ }^{16}$ may activate MAPKs pathways (ERK2, JNK1, and/or p38). These signalling cascades may serve as a common mechanism to interplay with other signalling pathways, in view of controlling cell responses to diverse stimuli ${ }^{24}$ (see Fig. 1). Polyphenolic compounds can modulate these MAPKs activities, which in turn regulate gene expression. ${ }^{24}$ Increasing evidence indicates that modulation of the activity of MAPKs is cell type and phenolic-dose dependent: for instance, apigenin and EGCG (Table 3) inhibit ERK1/2, JNK, and p38 MAPK in v-H-ras-transformed NIH 3 T3 cells ${ }^{30}$ and in human prostate cancer cell lines DU145 and $\mathrm{LNCaP}^{31}$ respectively. Other polyphenols, such as the flavonoid silymarin (Table 3), were found to inhibit ERK1/2 signalling in skin tumor cells.

\section{Suppression of Protein Kinases (PKs)}

The serine-threonine protein kinase $\mathrm{C}$ (PKC) comprises several isoforms and is a crucial component of the cell signaling cascades regulating signal transduction for tumor promotion, differentiation, and growth control, ${ }^{32}$ having a major role in carcinogenesis. PKC and IKK can activate NF- $\mathrm{BB}$, leading to the enhancement of expression of c-myc, inducible nitric oxide synthase (iNOS), and other proliferative genes. ${ }^{16}$ Both flavonoids (e.g., apigenin) and phenolic acid analogs (e.g., curcumin) (Tables I and III, respectively) are effective at inhibiting signal transduction enzymes, such as PKC ${ }^{33}$ or tyrosine kinases (PTK). ${ }^{34}$ For instance, curcumin inhibits PKC activity in 12 - $O$-tetradecanoylphorbol-13-acetate (TPA)-induced NIH 3 T3 cells $^{35}$ (see Table I). The stilbene resveratrol (Table II) has also been reported as implicated in the regulation of apoptosis, probably by inhibiting PKC activity in human gastric adenocarcinoma KATO-III cells. ${ }^{36}$ 


\section{E. Suppression of Growth-Factor Receptor (GFR)-Mediated Pathways}

Growth factor receptor-mediated pathways promote cell proliferation and tumor progression, ${ }^{37}$ which can be mediated by overexpression of growth receptors, abundance of growth factors and/or increased activities of the associated PTKs. Compounds that interfere with any of the components of this signaling cascade present chemopreventive properties. For instance, ECGC (Table III) can: (i) block the binding of epidermal growth factor (EGF) to epidermal growth factor receptor EGFR in A431 epidermoid carcinoma cells; ${ }^{38}$ (ii) inhibit EGFR autophosphorylation in YCU-N861 and YCUH891 head and neck carcinoma ${ }^{39}$ and MDA-MB-231 breast carcinoma cell lines; ${ }^{40}$ and (iii) inhibit tyrosine kinase activity in vitro. ${ }^{41}$ On the other hand, resveratrol (Table II) inhibits: (i) EGF expression in Ishikawa endometrial cancer cells, ${ }^{42}$ and (ii) tyrosine kinase activity in placenta. ${ }^{43}$ Curcumin (Table I) inhibits EGF kinase activity in A431 cells. ${ }^{44}$ The dietary flavonoid quercetin (Table III) suppresses tumor growth in DMBA-induced rat mammary tumors by inhibiting PTK. ${ }^{45}$

\section{F. Cell Cycle Arrest and Induction of Apoptosis}

Cell cycle deregulation and overexpression of growth promotion kinases [e.g., cyclin D1 and cyclindependent kinases (CDKs)] are accepted to be associated with carcinogenesis. ${ }^{46}$ Recent studies have shown that polyphenols can inhibit different cells at different cell phases: G1, S, S/G2, and G2 ${ }^{47}$ (see also Fig. 2). Nevertheless, the effects on cell cycle arrest can be either direct or indirect. EGCG has been shown to directly inhibit CDKs, ${ }^{48}$ or indirectly by inducing the expression of p21 and p27 genes and inhibiting the expression of cyclin $\mathrm{d} 1$ and $\mathrm{Rb}$ phosphorylation. ${ }^{46,48,49}$ Resveratrol was shown to arrest HL-60 cells at the S/G2-phase transition and subsequently increase the cell number in the G1/S phases, due to an overexpression of cyclins $\mathrm{A}$ and $\mathrm{E}$ without modification of $\mathrm{p} 21$ expression. ${ }^{50} \mathrm{In}$ addition it has been found that caffeic acid phenethyl ester (CAPE, Table I) is also able to cause growth arrest in human leukemia HL-60 cells. ${ }^{51}$ More recently, resveratrol was shown to induce apoptosis, preferentially in cells arrested in the G0/G1-phase, ${ }^{52}$ probably due to a decrease in Bcl-2 expression. Therefore, cell cycle arrest can represent a chemopreventive mechanism by subsequent induction of apoptosis.

Apoptosis is regulated by several proteins, including $\mathrm{p} 53$, and the $\mathrm{Bcl}-2$ and caspase families ${ }^{53}$ (Fig. 2). Several chemopreventive agents, especially at high concentrations, can activate the interleukin-1 $\beta$ (IL-1 $\beta$ ) converting enzyme/caernohabditis elegans ced-3 gene (ICE/Ced-3) protease (caspase) pathway. ${ }^{16}$ Activation of these cell death proteins may be beneficial if it occurs in preneoplastic or tumor cells, but it may result in toxicity when taking place in normal cells. Nevertheless, some phenolic compounds such as curcumin seem to induce apoptosis only in immortalized (malignant) cells: immortalized mouse embryo fibroblasts NIH 3T3, erB2, mouse Sarcoma 180, human colon cancer cell HT29, human kidney cancer cell 293, and human hepatocellular carcinoma HepG2 cells $^{54}$ (see also Table I). Moreover, other polyphenols such as resveratrol trigger apoptosis in carcinoma cells: Hep-G2 cells, ${ }^{55}$ acute lymphoblastic leukemia cells, ${ }^{56}$ THP-1 human monocytic leukemia cells ${ }^{57}$ and oral cancer cell lines, ${ }^{58}$ and EGCG induces apoptosis in H661 lung cancer cells. $^{59}$

\section{G. Antioxidant and Anti-Inflammatory Effects}

One relevant aspect of carcinogenesis is recognized to be the involvement of the inflammatory response, which may be prevented by hindering oxidative stress conditions, namely through phenolic antioxidants. The aromatic nature of polyphenols makes them potential targets of proinflammatory oxidants such as hypochlorous acid $(\mathrm{HOCl})$ and peroxynitrite $\left(\mathrm{ONO}_{2}{ }^{-}\right){ }^{60}$ This kind of reactive oxygen/nitrogen species (ROS/RNS) are formed as a consequence of normal and abnormal metabolic reactions, namely recruitment of inflammatory cells into tumor tissues (exponentionally enhancing ROS). ${ }^{60}$ ROS can damage proteins, DNA and RNA, as well as oxidize fatty acids in cell membranes 


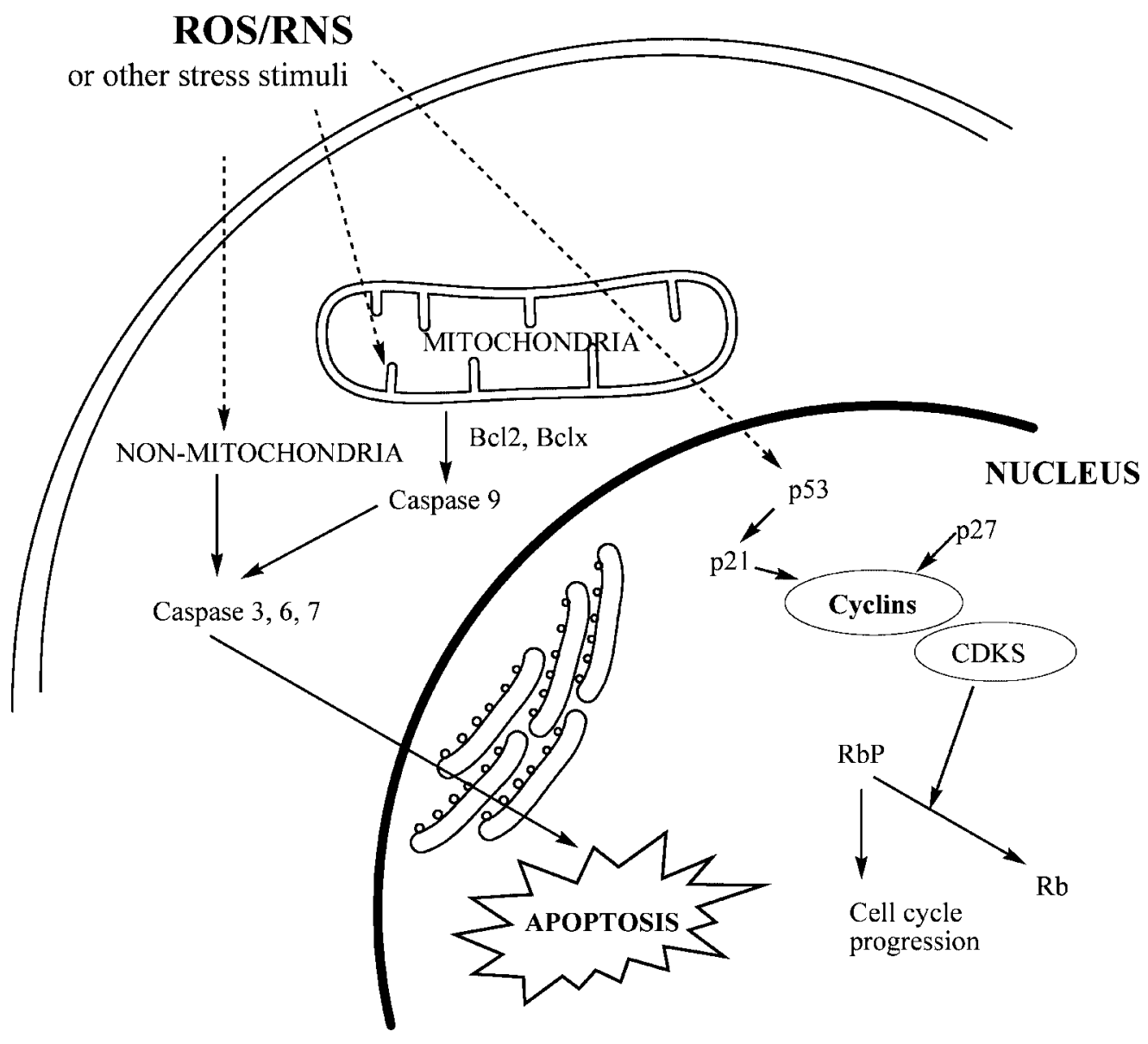

Figure 2. Reactive oxygen/nitrogen species (ROS/RNS) and other stress stimuli can interfere with the cell cycle regulation (increasing expression of cell cycle regulatory genes such as p53, cyclins, and CDKs), activation of caspase cascades and induction of apoptosis. These pathways are also described as possible targets for chemoprevention.

thus increasing the risk of mutations. However, most of the damage caused by ROS is restored by internal surveillance and repair systems. ${ }^{61}$ On the other hand, ROS can play important roles in a variety of normal processes in the body and are considered as endogenous mitogenic factors that may also activate NF- $\mathrm{\kappa B}$ and other transcription factors into the nucleus. ${ }^{62}$

One of the chemoprevention mechanisms of phenolic compounds is associated to their scavenging properties of deleterious reactive species (e.g., superoxide anion, hydroxyl radical, singlet oxygen, nitric oxide, and peroxynitrite). ${ }^{60}$ Alternatively, polyphenols can inhibit ROS generating transcription factors closely linked to inflammation (e.g., NF- $\mathrm{BB}^{24}$ ) and enzymes such as xanthine oxidase (XO) $\left(\right.$ curcumin $\left.^{63}\right)$, COX-2 $\left(\right.$ curcumin $\left.^{64}\right)$ or LOX (curcumin, silymarin, and resveratrol $^{65}$ ) that mediate inflammatory processes. ${ }^{66}$

Polyphenols can also behave as detoxifying enzyme inducers, modulating gene expression including induction of phase II enzymes, such as glutathione S-transferases (GST) and quinone reductases $(\mathrm{QR})$, which usually leads to protection of cells/tissues against exogenous and/or endogenous carcinogenic intermediates. ${ }^{67}$ The antioxidant/electrophile response element (ARE/EpRE) found at the $5^{\prime}$-flanking region of these phase II genes may play important roles in mediating their induction by xenobiotics (including phenolic compounds ${ }^{68}$ ). Phase II gene inducers also activate MAPK kinases and are involved in the transcription activation of ARE-mediated reporter gene. ${ }^{68}$ 


\section{H. Suppression of Angiogenesis}

Angiogenesis is characterized by the formation of new vessels from a pre-existing microvascular network, these new vessels acting as gateways for cancer cells to enter the bloodstream and spread to distant organs (contributing to the formation of metastasis). This process is mediated by modulation of proliferation and gene expression by endothelial cells. Inhibition of angiogenesis is recognized as a promising therapeutic approach for the control of tumor growth, progression, invasion, and metastasis. $^{69}$

Quercetin (Table III) is a polyphenol able to inhibit proliferation, migration, and tube formation of human microvascular dermal endothelial cells. These effects were hypothesized to be due to a decrease in both the expression and activity of matrixmetalloproteinase- $2 .{ }^{70}$ Resveratrol, in turn, inhibits vascular endothelial growth factor (VEGF)-induced angiogenesis by disrupting the activation of reactive oxygen species-dependent Src kinase. ${ }^{71}$ Phenolic acids and their analogs (Table I) can also act through this chemopreventive mechanism.

\section{Other Possible Targets}

Recent studies have suggested new possible mechanisms of chemoprevention. However, information on these specific mechanisms is still scarce and reported for a limited number of phenolic compounds. These mechanisms can be described as follows: (i) inhibition of DNA methyltransferases and consequent reactivation of key tumor suppressor gene p16, in human esophageal squamous cell carcinoma line KYSE $510\left(\mathrm{EGCG}^{72}\right)$; (ii) inhibition of topoisomerase I in various human colon cancer cell lines $\left(\mathrm{EGCG}^{73}\right)$; (iii) inhibition of telomerase both in vitro and in cancer xenographs (epicatechin, quercetin, and $\mathrm{EGCG}^{74}$ ); (iv) inhibition of expression of cell-adhesion molecules, namely ICAM-1 and VCAM-1 by TNF $\alpha$-stimulated human umbilical vein endothelial cells (HUVEC) and LPS-stimulated: human saphenous vein endothelial cells (HSVEC) probably via downregulation of NF- $\kappa \mathrm{B}$ (resveratrol ${ }^{75}$ ); and (v) inhibition of androgen receptor effects in LNCaP prostate cancer cell line, by repressing androgen receptor upregulated genes such as prostate-specific antigen (PSA) or androgen receptor-specific co-activator ARA70 (resveratrol ${ }^{76}$ ).

\section{FUTURE PERSPE CTIVES}

In recent years, numerous phenolic agents present in the human diet have been described to show a wide range of chemopreventive effects. This kind of studies yielded overwhelming evidence for cellular mechanisms of carcinogenesis to be susceptible to modification by biologically active constituents of food. However, much remains to be learned on the relationships between dietary intake of polyphenol-containing food and cancer. Nevertheless, it is the authors' belief that future efforts on the prevention of cancer are undoubtly related to dietary interventions as a mean of introducing chemopreventive agents to large populations at normal or increased risk. For achieving this end, clinical studies will be of great help for investigating the effect of polyphenols in human health. Clinical trials in humans are, therefore, urgently needed, in addition to the in vitro and in vivo animal experiments, described in the present review.

Research efforts are placing increasing emphasis on identifying the biological mechanisms and in particular the signal transduction pathways related to the chemopreventive activity of phenolic compounds. These effects are believed to be mediated by the regulation of signaling pathways, including NF- $\mathrm{B}$, AP-1, MAPK. We believe that polyphenols can exert their effects on these pathways either separately or sequentially, and possible crosstalk between these pathways cannot be overlooked. By modulating cell signaling pathways, polyphenols activate cell death signals and induce apoptosis in preneoplastic or neoplastic cells, thus inhibiting cancer development and/or progression. However, the regulation of cell signaling pathways by dietary polyphenols can also lead 
to cell proliferation/survival, and inflammatory responses due to increased expression of specific genes which increases largely the complexity of such studies.

In addition to mechanistic studies the authors strongly believe that it is also of utmost importance to perform structure-property-activity studies on chemopreventive dietary polyphenolic systems (since there is at present an evident lack of such data in the literature). In fact, only a combined effort, gathering results yielded by a wide range of methods - from biological to physico-chemical—will allow to achieve this final goal. Hopefully, a suitable database can be built in a near future, using our work and the research of other groups, in view of obtaining reliable SAR's (structure-activity relationships) and QSAR's (quantitative structure-activity relationships) for this important group of dietary compounds. ${ }^{77-80}$

The cancer-chemopreventive efficacy of dietary constituents is presently the subject of intense research, aiming at helping health professionals to answer questions about the preventive role of diet and its supplementation. On account of their safety and of the fact that they are not perceived as "medicines," food-derived products are highly interesting for development as effective chemopreventive agents. Dietary constituents with such properties are prone to find widespread, long-term use among the population with positive results. Epidemiological studies from Japanese population, for instance, suggested that daily consumption of ten or more small cups of green tea (corresponding to $1 \mathrm{~g} /$ day of green tea polyphenols) conferred significant protection from cancer. ${ }^{81}$ Curcumin has also been reported to decrease colorectal cancer risk in Asian populations. ${ }^{82}$

Phenolic acids account for about one-third of the total daily intake in a normal human diet, while flavonoids account for the remaining two-thirds. This current intake however, is often insufficient to protect from mutagens (either exogenous or endogenous), which leads to the need for dietary supplementation as an alternative approach. Despite the unequivocal importance of phenolic compounds as chemopreventive/chemotherapeutic agents, and although most of them are considered safe, the authors believe that consumption of this kind of dietary supplements must be preceded by careful studies. In fact, toxic flavonoid-drug interactions, liver failure, dermatitis, and anemia were reported for some cases of polyphenol chemopreventive use. ${ }^{83}$ These potential toxic effects of phenolic compounds are associated to the reported equilibrium between their antioxidant and prooxidant properties, ${ }^{84}$ strongly dependent on their concentration and chemical environment, which must be thoroughly understood before any preventive/therapeutic use is considered. In conclusion, further mechanistic insights are needed as well as an accurate knowledge of the concentrations of the chemopreventive agents and their metabolites occurring in humans.

\section{ABB REVIATIONS}

$\begin{array}{ll}\text { AP-1 } & \text { activator protein-1 } \\ \text { ARE/EpRE } & \begin{array}{l}\text { antioxidant response element/electrophile response element } \\ \text { activating transcription factor }\end{array} \\ \text { ATF } & \text { caffeic acid phenethyl ester } \\ \text { CAPE } & \text { cyclin-dependent kinase } \\ \text { CDKs } & \text { cyclooxygenase type } 2 \\ \text { COX-2 } & \text { cyclic AMP response element } \\ \text { CRE } & \text { 7,12-dimethylbenz[a]anthracene } \\ \text { DMBA } & \text { epigallocatechin-3-gallate } \\ \text { EGCC } & \text { epidermal growth factor } \\ \text { EGF } & \text { epidermal growth factor receptor } \\ \text { EGFR } & \text { extracellular signal-regulated protein kinases } \\ \text { ERKs } & \text { glutathione reductase } \\ \text { GST } & \text { human saphenous vein endothelial cells } \\ \text { HSVEC } & \end{array}$


HUVEC human umbilical vein endothelial cells

ICE/Ced-3 interleukin-1 $\beta$ (IL-1 $\beta$ ) converting enzyme/caernohabditis elegans ced-3gene

$\mathrm{I}-\kappa \mathrm{B}$

IKK I-KB kinase

iNOS inducible nitric oxide synthase

JDP-1/JDP-2 AP-1 repressor proteins

JNK c-Jun $N$-terminal kinase

LOX lipoxygenase

LPS lipopolysaccharide

MAPK mitogen-activated protein kinase

MEK MAPK kinase

MEKK MAPK/ERK kinase kinase

$\mathrm{NF}-\kappa \mathrm{B} \quad$ nuclear factor- $\kappa \mathrm{B}$

NIK NF- $\kappa \mathrm{B}$ inducing kinase

PKC protein kinase $\mathrm{C}$

PMA phorbol 12-myristate 13-acetate

PSA prostate-specific antigen

PTK protein tyrosine kinase

ROS/RNS reactive oxygen species/reactive nitrogen species

SRE serum response element

$\mathrm{TNF} \alpha \quad$ tumor necrosis factor alpha

TPA 12-O-tetradecanoyl-phorbol-13-acetate

TNFR tumor necrosis factor receptor

TRE TPA response element

VGEF vascular endothelial growth factor

$\mathrm{XO} \quad \mathrm{xanthine}$ oxidase

\section{RE FE REN CES}

1. Slaga TJ, Fisher SM, Weeks CE, Lein-Szanto AJP. Multistage carcinogenesis. In: Seije M, Bernstein IA, editors. Biochemistry of normal and abnormal epidermal differentiation. Tokyo: University of Tokyo Press; 1980. pp 19-38.

2. Pitot HC. Progression: the terminal stage in carcinogenesis. Jpn J Cancer Res 1989;80:599-607.

3. Stanley LA. Molecular aspects of chemical carcinogenesis: The roles of oncogenes and tumour suppressor genes. Toxicology 1995;96:173-194.

4. Morse MA, Stoner GD. Cancer chemoprevention: Principles and prospects. Carcinogenesis 1993;14: 1737-1746.

5. Kelloff GJ, Boone CW, Crowell JA, Nayfield SG, Hawk E, Malone WF, Steele VE, Lubet RA, Sigman CC. Risk biomarkers and current strategies for cancer chemoprevention. J Cell Biochem Suppl 1996;25: $1-14$.

6. Kelloff GJ, Hawk ET, Karp JE, Crowell JA, Boone CW, Steele VE, Lubet RA, Sigman CC. Progress in clinical chemoprevention. Semin Oncol 1997;24:241-252.

7. Wattenberg LW. Chemoprevention of cancer. Cancer Res 1985;45:1-8.

8. Surh YJ. Cancer chemoprevention with dietary phytochemicals. Nat Rev Cancer 2003;3:768-780.

9. De Flora S. Mechanisms of inhibitors of mutagenesis and carcinogenesis. Mutat Res 1998;402:151158.

10. Rao CV, Desai D, Rivenson A, Simi B, Amin S, Reddy BS. Chemoprevention of colon carcinogenesis by phenylethyl-3-methylcaffeate. Cancer Res 1995;55:2310-2315.

11. Tapiero H, Tew KD, Ba GN, Mathe G. Polyphenols: Do they play a role in the prevention of human pathologies? Biomed Pharmacother 2002;56:200-207.

12. Fiuza SM, Gomes C, Teixeira LJ, Girao da Cruz MT, Cordeiro MN, Milhazes N, Borges F, Marques MPM. Phenolic acid derivatives with potential anticancer properties—a structure-activity relationship study. Part 1: Methyl, propyl and octyl esters of caffeic and gallic acids. Bioorg Med Chem 2004;12:3581-3589. 
13. Gomes CA, da Cruz TG, Andrade JL, Milhazes N, Borges F, Marques MPM. Anticancer activity of phenolic acids of natural or synthetic origin: A structure-activity study. J Med Chem 2003;46:5395-5401.

14. Mahmoud NN, Carothers AM, Grunberger D, Bilinski RT, Churchill MR, Martucci C, Newmark HL, Bertagnolli MM. Plant phenolics decrease intestinal tumors in an animal model of familial adenomatous polyposis. Carcinogenesis 2000;21:921-927.

15. Kelloff GJ. Perspectives on cancer chemoprevention research and drug development. Adv Cancer Res 2000;78:199-334.

16. Kong AN, Yu R, Hebbar V, Chen C, Owuor E, Hu R, Ee R, Mandlekar S. Signal transduction events elicited by cancer prevention compounds. Mutat Res 2001;480-481:231-241.

17. Yang F, Oz HS, Barve S, de Villiers WJ, McClain CJ, Varilek GW. The green tea polyphenol (-)epigallocatechin-3-gallate blocks nuclear factor- $\mathrm{KB}$ activation by inhibiting I- $\mathrm{KB}$ kinase activity in the intestinal epithelial cell line IEC-6. Mol Pharmacol 2001;60:528-533.

18. Pan MH, Lin-Shiau SY, Ho CT, Lin JH, Lin JK. Suppression of lipopolysaccharide-induced nuclear factor$\kappa B$ activity by theaflavin-3,3'-digallate from black tea and other polyphenols through down-regulation of I- $\mathrm{kB}$ kinase activity in macrophages. Biochem Pharmacol 2000;59:357-367.

19. Ahmad N, Gupta S, Mukhtar H. Green tea polyphenol epigallocatechin-3-gallate differentially modulates nuclear factor $\mathrm{\kappa B}$ in cancer cells versus normal cells. Arch Biochem Biophys 2000;376:338-346.

20. Manna SK, Mukhopadhyay A, Aggarwal BB. Resveratrol suppresses TNF-induced activation of nuclear transcription factors NF-KB, activator protein-1, and apoptosis: Potential role of reactive oxygen intermediates and lipid peroxidation. J Immunol 2000;164:6509-6519.

21. Lo AH, Liang YC, Lin-Shiau SY, Ho CT, Lin JK. Carnosol, an antioxidant in rosemary, suppresses inducible nitric oxide synthase through down-regulating nuclear factor- $\kappa \mathrm{B}$ in mouse macrophages. Carcinogenesis 2002;23:983-991.

22. Huang SC, Ho CT, Lin-Shiau SY, Lin JK. Carnosol inhibits the invasion of B16/F10 mouse melanoma cells by suppressing metalloproteinase-9 through down-regulating nuclear factor-kappa B and c-Jun. Biochem Pharmacol 2005;69:221-232.

23. Eferl R, Wagner EF. AP-1: A double-edged sword in tumorigenesis. Nat Rev Cancer 2003;3:859-868.

24. Kundu JK, Surh YJ. Molecular basis of chemoprevention by resveratrol: NF- $\mathrm{KB}$ and AP-1 as potential targets. Mutat Res 2004;555:65-80.

25. Halazonetis TD, Georgopoulos K, Greenberg ME, Leder P. c-Jun dimerizes with itself and with c-Fos, forming complexes of different DNA binding affinities. Cell 1988;55:917-924.

26. Karin M. The regulation of AP-1 activity by mitogen-activated protein kinases. J Biol Chem 1995; 270:16483-16486.

27. Yu R, Hebbar V, Kim DW, Mandlekar S, Pezzuto JM, Kong AN. Resveratrol inhibits phorbol ester and UV-induced activator protein 1 activation by interfering with mitogen-activated protein kinase pathways. Mol Pharmacol 2001;60:217-224.

28. Dong Z, Ma W, Huang C, Yang CS. Inhibition of tumor promoter-induced activator protein 1 activation and cell transformation by tea polyphenols, (-)-epigallocatechin gallate, and theaflavins. Cancer Res 1997;57:4414-4419.

29. Yoshioka K, Deng T, Cavigelli M, Karin M. Antitumor promotion by phenolic antioxidants: Inhibition of AP-1 activity through induction of Fra expression. Proc Natl Acad Sci USA 1995;92:4972-4976.

30. Kuo ML, Yang NC. Reversion of v-H-ras-transformed NIH 3T3 cells by apigenin through inhibiting mitogen activated protein kinase and its downstream oncogenes. Biochem Biophys Res Commun 1995;26:767-775.

31. Siddiqui IA, Adhami VM, Afaq F, Ahmad N, Mukhtar H. Modulation of phosphatidylinositol-3-kinase/ protein kinase B- and mitogen-activated protein kinase-pathways by tea polyphenols in human prostate cancer cells. J Cell Biochem 2004;91:232-242.

32. Livneh E, Fishman DD. Linking protein kinase C to cell-cycle control. Eur J Biochem 1997;248:1-9.

33. Lin JK, Chen YC, Huang YT, Lin-Shiau SY. Suppression of protein kinase C and nuclear oncogene expression as possible molecular mechanisms of cancer chemoprevention by apigenin and curcumin. J Cell Biochem 1997;28-29(Suppl):39-48.

34. Markovits J, Linassier C, Fosse P, Couprie J, Pierre J, Jacquemin-Sablon A, Saucier JM, Le Pecq JB, Larsen AK. Inhibitory effects of the tyrosine kinase inhibitor genistein on mammalian DNA topoisomerase II. Cancer Res 1989;49:5111-5117.

35. Liu JY, Lin SJ, Lin JK. Inhibitory effects of curcumin on protein kinase C activity induced by 12-Otetradecanoyl-phorbol-13-acetate in NIH 3T3 cells. Carcinogenesis 1993;14:857-861.

36. Atten MJ, Attar BM, Milson T, Holian O. Resveratrol-induced inactivation of human gastric adenocarcinoma cells through a protein kinase C-mediated mechanism. Biochem Pharmacol 2001;62: $1423-1432$. 
37. Mendelsohn J, Baselga J. The EGF receptor family as targets for cancer therapy. Oncogene 2000;19:65506565.

38. Liang YC, Chen YC, Lin YL, Lin-Shiau SY, Ho CT, Lin JK. Suppression of extracellular signals and cell proliferation by the black tea polyphenol, theaflavin-3,3'-digallate. Carcinogenesis 1999;20:733-736.

39. Masuda M, Suzui M, Weinstein IB. Effects of epigallocatechin-3-gallate on growth, epidermal growth factor receptor signaling pathways, gene expression, and chemosensitivity in human head and neck squamous cell carcinoma cell lines. Clin Cancer Res 2001;7:4220-4229.

40. Masuda M, Suzui M, Lim JT, Deguchi A, Soh JW, Weinstein IB. Epigallocatechin-3-gallate decreases VEGF production in head and neck and breast carcinoma cells by inhibiting EGFR-related pathways of signal transduction. J Exp Ther Oncol 2002;2:350-359.

41. Liang YC, Lin-shiau SY, Chen CF, Lin JK. Suppression of extracellular signals and cell proliferation through EGF receptor binding by (-)-epigallocatechin gallate in human A431 epidermoid carcinoma cells. J Cell Biochem 1997;67:55-65.

42. Kaneuchi M, Sasaki M, Tanaka Y, Yamamoto R, Sakuragi N, Dahiya R. Resveratrol suppresses growth of Ishikawa cells through down-regulation of EGF. Int J Oncol 2003;23:1167-1172.

43. Palmieri L, Mameli M, Ronca G. Effect of resveratrol and some other natural compounds on tyrosine kinase activity and on cytolysis. Drugs Exp Clin Res 1999;25:79-85.

44. Korutla L, Kumar R. Inhibitory effect of curcumin on epidermal growth factor receptor kinase activity in A431 cells. Biochim Biophys Acta 1994;1224:597-600.

45. Levy J, Teuerstein I, Marbach M, Radian S, Sharoni Y. Tyrosine protein kinase activity in the DMBAinduced rat mammary tumor: Inhibition by quercetin. Biochem Biophys Res Commun 1984;123:12271233.

46. Semczuk A, Jakowicki JA. Alterations of pRb1-cyclin D1-cdk4/6-p16(INK4A) pathway in endometrial carcinogenesis. Cancer Lett 2004;203:1-12.

47. Gusman J, Malonne H, Atassi G. A reappraisal of the potential chemopreventive and chemotherapeutic properties of resveratrol. Carcinogenesis 2001;22:1111-1117.

48. Liang YC, Lin-Shiau SY, Chen CF, Lin JK, Inhibition of cyclin-dependent kinases 2 and 4 activities as well as induction of Cdk inhibitors p21 and p27 during growth arrest of human breast carcinoma cells by (-)epigallocatechin-3-gallate. J Cell Biochem 1999;75:1-12.

49. Salomon DS, Brandt R, Ciardiello F, Normanno N. Epidermal growth factor-related peptides and their receptors in human malignancies. Crit Rev Oncol Hematol 1995;19:183-232.

50. Suh N, Luyengi L, Fong HH, Kinghorn AD, Pezzuto JM. Discovery of natural product chemopreventive agents utilizing HL-60 cell differentiation as a model. Anticancer Res 1995;15:233-239.

51. Chen JH, Shao Y, Huang MT, Chin CK, Ho CT. Inhibitory effect of caffeic acid phenethyl ester on human leukemia HL-60 cells. Cancer Lett 1996;108:211-214.

52. Surh YJ, Hurh YJ, Kang JY, Lee E, Kong G, Lee SJ. Resveratrol, an antioxidant present in red wine, induces apoptosis in human promyelocytic leukemia (HL-60) cells. Cancer Lett 1999;140:1-10.

53. Leu TH, Maa MC. The molecular mechanisms for the antitumorigenic effect of curcumin. Curr Med Chem Anti-Canc Agents 2002;2:357-370.

54. Jiang MC, Yang-Yen HF, Yen JJ, Lin JK. Curcumin induces apoptosis in immortalized NIH 3 T3 and malignant cancer cell lines. Nutr Cancer 1996;26:111-120.

55. Kuo PL, Chiang LC, Lin CC. Resveratrol-induced apoptosis is mediated by p53-dependent pathway in Hep G2 cells. Life Sci 2002;72:23-34.

56. Dorrie J, Gerauer H, Wachter Y, Zunino SJ. Resveratrol induces extensive apoptosis by depolarizing mitochondrial membranes and activating caspase-9 in acute lymphoblastic leukemia cells. Cancer Res 2001;61:4731-4739.

57. Tsan MF, White JE, Maheshwari JG, Bremner TA, Sacco J. Resveratrol induces Fas signallingindependent apoptosis in THP-1 human monocytic leukaemia cells. Br J Haematol 2000;109:405-412.

58. Hsu S, Singh B, Schuster G. Induction of apoptosis in oral cancer cells: Agents and mechanisms for potential therapy and prevention. Oral Oncol 2004;40:461-473.

59. Yang GY, Liao J, Kim K, Yurkow EJ, Yang CS. Inhibition of growth and induction of apoptosis in human cancer cell lines by tea polyphenols. Carcinogenesis 1998;19:611-616.

60. D’Alessandro T, Prasain J, Benton MR, Botting N, Moore R, Darley-Usmar V, Patel R, Barnes S. Polyphenols, inflammatory response, and cancer prevention: Chlorination of isoflavones by human neutrophils. J Nutr 2003;133:3773S-3777S.

61. Ruffin MT IV, Rock CL. Do antioxidants still have a role in the prevention of human cancer? Curr Oncol Rep 2001;3:306-313.

62. Kovacic P, Jacintho JD. Mechanisms of carcinogenesis: Focus on oxidative stress and electron transfer. Curr Med Chem 2001;8:773-796. 
63. Lin JK, Shih CA. Inhibitory effect of curcumin on xanthine dehydrogenase/oxidase induced by phorbol12-myristate-13-acetate in NIH3T3 cells. Carcinogenesis 1994;15:1717-1721.

64. Zhang F, Altorki NK, Mestre JR, Subbaramaiah K, Dannenberg AJ. Curcumin inhibits cyclooxygenase-2 transcription in bile acid- and phorbol ester-treated human gastrointestinal epithelial cells. Carcinogenesis 1999;20:445-451.

65. Hong J, Smith TJ, Ho CT, August DA, Yang C. Effects of purified green and black tea polyphenols on cyclooxygenase- and lipoxygenase-dependent metabolism of arachidonic acid in human colon mucosa and colon tumor tissues. Biochem Pharmacol 2001;62:1175-1183.

66. Le Corre L, Chalabi N, Delort L, Bignon YJ, Bernard-Gallon DJ. Resveratrol and breast cancer chemoprevention: Molecular mechanisms. Mol Nutr Food Res 2005;49:462-471.

67. Fiander H, Schneider H. Dietary ortho polyphenols that induce glutathione S-transferase and increase the resistance of cells to hydrogen peroxide are potential cancer chemopreventives that act by two mechanisms: The alleviation of oxidative stress and the detoxification of mutagenic xenobiotics. Cancer Lett 2000;156:117-124.

68. Chen C, Kong NA. Dietary chemopreventive compounds and ARE/EpRE signaling. Free Radic Biol Med 2004;36:1505-1516.

69. Gourley M, Williamson JS. Angiogenesis: New targets for the development of anticancer chemotherapies. Curr Pharm Des 2000;6:417-439.

70. Tan WF, Lin LP, Li MH, Zhang YX, Tong YG, Xiao D, Ding J. Quercetin, a dietary-derived flavonoid, possesses antiangiogenic potential. Eur J Pharmacol 2003;459:255-262.

71. Lin MT, Yen ML, Lin CY, Kuo ML. Inhibition of vascular endothelial growth factor-induced angiogenesis by resveratrol through interruption of Src-dependent vascular endothelial cadherin tyrosine phosphorylation. Mol Pharmacol 2003;64:1029-1036.

72. Fang MZ, Wang Y, Ai N, Hou Z, Sun Y, Lu H, Welsh W, Yang CS. Tea polyphenol (-)-epigallocatechin-3gallate inhibits DNA methyltransferase and reactivates methylation-silenced genes in cancer cell lines. Cancer Res 2003;63:7563-7570.

73. Berger SJ, Gupta S, Belfi CA, Gosky DM, Mukhtar H. Green tea constituent (-)-epigallocatechin-3gallate inhibits topoisomerase I activity in human colon carcinoma cells. Biochem Biophys Res Commun 2001;288:101-105.

74. Naasani I, Oh-Hashi F, Oh-Hara T, Feng WY, Johnston J, Chan K, Tsuruo T. Blocking telomerase by dietary polyphenols is a major mechanism for limiting the growth of human cancer cells in vitro and in vivo. Cancer Res 2003;63:824-830.

75. Ferrero ME, Bertelli AA, Pellegatta F, Fulgenzi A, Corsi MM, Bertelli A. Phytoalexin resveratrol (3-4'-5trihydroxystilbene) modulates granulocyte and monocyte endothelial adhesion. Transplant Proc 1998;30:4191-4193.

76. Mitchell SH, Zhu W, Young CY. Resveratrol inhibits the expression and function of the androgen receptor in LNCaP prostate cancer cells. Cancer Res 1999;59:5892-5895.

77. Lee YJ, Liao PH, Chen WK, Yang CY. Preferential cytotoxicity of caffeic acid phenethyl ester analogues on oral cancer cells. Cancer Lett 2000;153:51-56.

78. van Zanden JJ, Geraets L, Wortelboer HM, van Bladeren PJ, Rietjens IM, Cnubben NH. Structural requirements for the flavonoid-mediated modulation of glutathione S-transferase P1-1 and GS-X pump activity in MCF7 breast cancer cells. Biochem Pharmacol 2004;67:1607-1617.

79. Farkas O, Jakus J, Héberger K. Quantitative structure—antioxidant activity relationships of flavonoid compounds. Molecules 2004;9:1079-1088.

80. Thakur A, Vishwakarma S, Thakur M. QSAR study of flavonoid derivatives as p56lck tyrosinkinase inhibitors. Bioorg Med Chem 2004;12:1209-1214.

81. Imai K, Suga K, Nakachi K. Cancer-preventive effects of drinking green tea among a Japonese population. Prev Med 1997;26:769-775.

82. Chauhan DP. Chemotherapeutic potential of curcumin for colorectal cancer. Curr Pharm Des 2002;8: $1695-1706$

83. Galati G, O'Brien P. Potential toxicity of flavonoids and other dietary phenolics: Significance for their chemopreventive and anticancer properties. Free Radic Biol Med 2004;37:287-303.

84. Cao G, Sofic E, Prior RL. Antioxidant and prooxidant behaviour of flavonoids: Structure-activity relationships. Free Radic Biol Med 1997;22:749-760.

85. Serrano A, Palacios C, Roy G, Cespon C, Villar ML, Nocito M, Gonzalez-Porque P. Derivatives of gallic acid induce apoptosis in tumoral cell lines and inhibit lymphocyte proliferation. Arch Biochem Biophys 1998;350:49-54.

86. Kampa M, Alexaki VI, Notas G, Nifli AP, Nistikaki A, Hatzoglou A, Bakogeorgou E, Kouimtzoglou E, Blekas G, Boskou D, Gravanis A, Castanas E. Antiproliferative and apoptotic effects of selective phenolic 
acids on T47D human breast cancer cells: Potential mechanisms of action. Breast Cancer Res 2004;6:R63-R74.

87. Taraphdar AK, Roy M, Bhattacharya RK. Natural products as inducers of apoptosis: Implication for cancer therapy and prevention. Curr Science 2001;80:1387-1396.

88. Lee YT, Don MJ, Hung PS, Shen YC, Lo YS, Chang KW, Chen CF, Ho LK. Cytotoxicity of phenolic acid phenethyl esters on oral cancer cells. Cancer Lett 2005;223:19-25.

89. Surh YJ. Molecular mechanisms of chemopreventive effects of selected dietary and medicinal phenolic substances. Mutat Res 1999;428:305-327.

90. Chung WY, Jung YJ, Surh YJ, Lee SS, Park KK. Antioxidative and antitumor promoting effects of [6]paradol and its homologs. Mutat Res 2001;496:199-206.

91. Bode AM, Dong Z. Targeting signal transduction pathways by chemopreventive agents. Mutat Res 2004;555:33-51.

92. Petersen M, Simmonds MS. Rosmarinic acid. Phytochemistry 2003;62:121-125.

93. Babich H, Visioli F. In vitro cytotoxicity to human cells in culture of some phenolics from olive oil. Farmaco 2003;58:403-407.

94. Ren W, Qiao Z, Wang H, Zhu L, Zhang L. Flavonoids: Promising anticancer agents. Med Res Rev 2003;3:519-534.

95. Cipak L, Rauko P, Miadokova E, Cipakova I, Novotny L. Effects of flavonoids on cisplatin-induced apoptosis of HL-60 and L1210 leukemia cells. Leuk Res 2003;27:65-72.

96. Wang J, Mazza G. Effects of anthocyanins and other phenolic compounds on the production of tumor necrosis factor alpha in LPS/IFN-gamma-activated RAW 264.7 macrophages. J Agric Food Chem 2002;50:4183-4189.

97. Hou DX, Fujii M, Terahara N, Yoshimoto M. Molecular mechanisms behind the chemopreventive effects of anthocyanidins. J Biomed Biotechnol 2004;2004:321-325.

98. Singh RP, Tyagi AK, Zhao J, Agarwal R. Silymarin inhibits growth and causes regression of established skin tumors in SENCAR mice via modulation of mitogen-activated protein kinases and induction of apoptosis. Carcinogenesis 2002;23:499-510.

99. Borges F, Roleira F, Milhazes N, Santana L, Uriarte E. Simple coumarins and analogues in medicinal chemistry: Occurrence, synthesis and biological activity. Curr Med Chem 2005;12:887-916.

100. Hibasami H, Fujikawa T, Takeda H, Nishibe S, Satoh T, Fujisawa T, Nakashima K. Induction of apoptosis by Acanthopanax senticosus HARMS and its component, sesamin in human stomach cancer KATO III cells. Oncol Rep 2000;7:1213-1216.

Paula Fresco received her degree in Pharmaceutical Sciences in 1992 from the University of Coimbra. She obtained her Ph.D. in Molecular Toxicology from the University of London in January1997, under the supervision of Dr Andreas Kortenkamp. She obtained a position at the University of Porto in 1995 and from November 2000 to present she has held a position of Assistant Professor in Pharmacology. Her main scientific interests relate to the pharmacology of adenosine receptors and possible therapeutic applications of phenolic compounds (cancer/inflammation).

Carmen Diniz received her degree in Pharmaceutical Sciences in 1992 from the University of Coimbra. She obtained her Master degree from the University of Porto in 1997. She obtained her Ph.D. in Pharmacology from the University of Porto in 2003, under the supervision of Dr Jorge Gonçalves. She obtained a position at the University of Porto in 1997 and from March 2003 to present she has held a position of Assistant Professor in Pharmacology. Her main scientific interests relate to the pharmacology of adenosine receptors and possible therapeutic applications of phenolic compounds (cancer/inflammation).

Fernanda Borges received her degree in Pharmacy in 1982 from the University of Porto, where she has held a position in the Faculty of Pharmacy since 1983. She obtained her Ph.D. in Medicinal Chemistry from the University of Porto in 1995. From this data to present she has held a position of Assistant Professor at the Faculty of Pharmacy, University of Porto. Her scientific interests have focused on Medicinal Chemistry: synthesis and structural elucidation of organic compounds with potential biological activity. This project encompasses the synthesis of antioxidant and anticancer compounds structurally based on the natural ones. 
Maria Paula Marques graduated in Chemistry by the Faculty of Sciences and Technology of the University of Coimbra in 1983. She concluded the Masters in Physical Chemistry in 1987 and the Ph.D. in Biochemistry (Bioinorganics) in 1995, in the University of Coimbra. From 1983 on she has been a definite Assistant Professor in the Faculty of Science and Technology of the University of Coimbra (Departments Chemistry and Biochemistry). She is a member of the Research Unit "Molecular Physical-Chemistry" of the University of Coimbra since 1996. She develops research work in the field of Medicinal Chemistry and Bioinorganics-namely in the investigation of the conformational analysis of phenolic derivatives as well as polyamines and their Pt(II) and Pd(II) chelates - using Vibrational Spectroscopy (Raman, FTIR, and INS), ab initio calculations, and cytotoxic evaluation assays. She is presently involved in the study of structure-activity relationships (SAR's) ruling the activity of new antioxidant and anticancer agents. 